\title{
DETERMINANTS OF CUSTOMER LOYALTY
}

\author{
Eva Indah ${ }^{1}$, Abdul Nasser Hasibuan ${ }^{2}$, Ali Hardana ${ }^{3}$, Rahmat Annam ${ }^{4}$ \\ ${ }^{1}$ IAIN Padangsidimpuan (Perbankan Syariah, FEBI, IAIN Padangsidimpuan) \\ ${ }^{2}$ IAIN Padangsidimpuan (Perbankan Syariah, FEBI, IAIN Padangsidimpuan) \\ ${ }^{3}$ IAIN Padangsidimpuan (Ekonomi Syariah, FEBI, IAIN Padangsidimpuan) \\ ${ }^{4}$ IAIN Padangsidimpuan (Ekonomi Syariah, FEBI, IAIN Padangsidimpuan) \\ Elnasriwanna@gmail.com ${ }^{1}$, hasibuanabdulnasser@iain-padangsidimpuan.ac.id ${ }^{2}$, alihardana@iain- \\ padangsidimpuan.ac.id $^{3}$, rahmatannam@iain-padangsidimpuan.ac.id ${ }^{4}$
}

\begin{abstract}
ABSTRAK
Penelitian ini bertujuan untuk mengetahui pengaruh kepuasan nasabah dan citra bank terhadap loyalitas nasabah pada Pt. Bank Muamalat Indonesia, Tbk., Kantor Cabang Pembantu Panyabungan. Terciptanya kepuasan nasabah dan citra bank yang baik merupakan keuntungan bagi bank. Kepuasan menjadi dasar yang baik bagi nasabah untuk mengulang kembali penggunaan jasa bank terkait sehingga nasabah tersebut menjadi loyal. Penelitian ini merupakan penelitian kuantitatif, data yang diperoleh dari penyebaran angket. Teknik pengumpulan sampel menggunakan rumus slovin sehingga diperoleh sampel sebanyak 83 orang nasabah. Analisis data dengan menggunakan regresi linear berganda. Hasil penelitian menunjukkan, secara parsial kepuasaan nasabah berpengaruh terhadap loyalitas nasabah dan citra bank berpengaruh terhadap loyalitas nasabah. Kemudian secara simultan kepuasan nasabah dan citra bank secara bersama-sama berpengaruh dan signifikan terhadap loyalitas nasabah.
\end{abstract}

Kata Kunci: Kepuasan Nasabah, Citra Bank, Loyalitas Nasabah

\begin{abstract}
This study aims to determine the effect of customer satisfaction and bank image on customer loyalty at Pt. Bank Muamalat Indonesia, Tbk., Panyabungan Sub-Branch Office. The creation of customer satisfaction and a good bank image is an advantage for banks. Satisfaction is a good basis for customers to repeat the use of related bank services so that these customers become loyal. This research is a quantitative study, data obtained from questionnaires. The sample collection technique uses the Slovin formula to obtain a sample of 83 customers. Data analysis using multiple linear regression. The results showed that customer satisfaction partially affected customer loyalty and the image of the bank affected customer loyalty. Then simultaneously customer satisfaction and the image of the bank together have a significant and significant effect on customer loyalty.
\end{abstract}

Keywords: Customer Satisfaction, Bank Image, Customer Loyalty 


\section{Journal of Sharia Banking}

\section{A. PENDAHULUAN}

PT Bank Muamalat Indonesia Tbk didirikan pada 24 Rabius Tsani 1412 H atau 01 November 1991, diprakarsai oleh Majelis Ulama Indonesia (MUI) dan Pemerintah Indonesia. Bank ini memulai operasinya pada 27 Syawal $1412 \mathrm{H}$ atau 01 Mei 1992, dengan dukungan nyata dari eksponen Ikatan Cendekiawan Muslim se Indonesia (ICMI) dan beberapa pengusaha Muslim yang kemudian mendapat dukungan dari Pemerintah Republik Indonesia.

PT. Bank Muamalat Indonesia, Tbk. KCP Panyabungan adalah cabang pembantu dari Bank Muamalat Indonesia Cabang Padangsidimpuan yang terletak di Jl. Willem Iskandar No. 173 Panyabungan Kelurahan Sipolu-polu Kecamatan Panyabungan, Kabupaten Mandailing Natal Provinsi Sumatera Utara. Daerah pemasaran PT. Bank Muamalat Indonesia Tbk KCP Panyabungan meliputi beberapa Kecamatan di Kabupaten Mandailing Natal, diantaranya Kecamatan Siabu, Panyabungan Utara, Panyabungan Selatan, Panyabungan Barat, Panyabungan Barat, Panyabungan Timur, Panyabungan Kota, Hutabargot, Puncak Sorik Marapi, Lembah Sorik Marapi, Kayu Laut, Natal, Kotanopan, Tambangan, Sinunukan, Batahan, Batang Natal. Hal tersebut dibuktikan dari adanya beberapa nasabah dari tempat tersebut.

\footnotetext{
Bank adalah badan usaha yang menghimpun dana dari masyarakat dalam
}

bentuk simpanan dan menyalurkannya kepada masyarakat dalam bentuk kredit atau pembiayaan serta jasa-jasa lainnya dalam rangka meningkatkan taraf hidup masyarakat. Perbankan Syariah merupakan sistem perbankan yang menjalankan kegiatan operasionalnya berdasarkan prinsip syariah. Dalam pasal 1 ayat (1) UU Nomor 21 Tahun 2008 tentang perbankan syariah menyatakan "perbankan syariah adalah segala sesuatau yang menyangkut tentang bank syariah dan unit usaha syariah, mencakup kelembagaan, kegiatan usaha, serta cara dan proses dalam melaksanakan kegiatan usahnya".

Bank merupakan salah satu urat nadi perekonomian sebuah negara, tanpa adanya bank bisa dibayangkan sulitnya menerima dan mengirim uang. Tidak hanya terpaku pada masalah kuantitas yang diberikan oleh bank, tetapi juga pada kualitas, baik mengenai produk perbankan yang ditawarkan, pelayanan yang diberikan, kepercayaan, maupun citra baik dari bank yang akhirnya berpengaruh pada loyalitas nasabah.

Loyalitas nasabah merupakan asset yang tidak ternilai bagi perbankan atau perusahaan. Karena loyalitas nasabah akan berdampak terhadap kinerja perusahaan dan dapat mempertahankan kelangsungan hidup perusahaan. Nasabah yang loyal mampu meningkatkan laba melalui peningkatan pendapatan, karena nasabah yang loyal selalu 
POINT Vol. 2, No. 1, Jul 2021

melakukan pembelian ulang dan memiliki kecenderungan membeli lebih banyak, mau membayar dengan harga yang lebih mahal yang akan berdampak secara langsung terhadap keuntungan yang diperoleh perusahaan.

Mempertahankan nasabah yang loyal memang harus mendapatkan prioritas yang utama daripada mendapat nasabah yang baru, karena untuk merekrut atau mendapatkan nasabah baru bukanlah hal yang mudah karena akan memerlukan biaya yang banyak, maka sangatlah rugi bila perusahaan melepas nasabah yang telah loyal secara begitu saja. Faktor-faktor yang mempengaruhi loyalitas nasabah yaitu, kepuasan nasabah, citra, kualitas jasa dan penanganan komplain.

Berdasarkan hasil wawancara dengan salah satu nasabah PT. Bank Muamalat Indonesia, Tbk. KCP Panyabungan, nasabah tersebut belum merasa puas dalam melakukan transakasi di PT. Bank Muamalat Indonesia, Tbk. KCP Panyabungan

Berdasarkan latar belakang di atas, maka judul penelitian yang diambil adalah "Determinan Loyalitas Nasabah".

\section{B. METODE}

Penelitan ini dilaksanakan di PT Bank Muamalat Indonesia, Tbk., Kantor Cabang Pembantu Panyabungan. Jenis penelitian yang digunakan pada penelitian ini adalah penelitian kuantitatif. Penelitian kuantitatif merupakan penelitian berupa angkaangka dan analisis menggunakan statistik, digunakan untuk meneliti pada populasi atau sampel tertentu, pengumpulan data menggunkan instrumen penelitian, analisis data bersifat kuantitatif/statistik, dengan tujuan untuk menguji hipotesis yang telah ditetapkan.

Uji validitas berguna untuk mengetahui apakah ada pertanyaan-pertanyaan pada kuesioner yang harus dibuang karena tidak relevan. Uji validitas dilakukan untuk melihat apakah item pernyataan valid atau tidak. Suatu item dikatakan valid apabila rhitung> rtabel. rtabel dicari pada tabel $r$ dengan terlebih dahulu mencari df-nya (degress of freedom) atau derajat kebebasan dengan rumus $\mathrm{df}=\mathrm{n}-2$. Penelitian ini menggunakan taraf signifikan $10 \%$.

Uji reliabilitas dilakukan terhadap item pertanyaan yang dinyatakan valid. Uji reliabilitas merupakan kendalan pengukuran dengan menggunkan Cronbach Alfa yang menunjukkan sebarapa baiknya item dalam suatu kumpulan secara positif berkorelasi satu sama lain. Uji reliabilitas dilakukan secara bersama-sama terhadap seluruh pernyataan. Dan suatu item dikatakan reliabel jika nilai Cronbach Alfa $>60$.

Teknik analisis data dalam penelitian ini menggunakan analisis regresi berganda. Data yang diperoleh dianalisis dengan menggunakan uji asumsis klasik, analisis regresi berganda (uji multikolinearitas dan uji heterokedastisitas), uji koefisien determinasi $\left(R^{2}\right)$ dan uji hipotesis (uji t dan uji F). 


\section{HASIL DAN PEMBAHASAN}

1. Uji Validitas

Uji validitas dilakukan dengan membandingkan nilai rhitung dengan nilai rtabel. Dimana rtabel dicari pada signifikan $10 \%$ atau 0,1 dengan derajat kebebasan $(d f)=n-2$, dimana $n=$ jumlah sampel, jadi df (degress of freedom) $=83-$ 2=81, maka diperoleh rtabel sebesar 0,181. Sedangkan rhitung dapat dilihat pada hasil Coreccted Item Total Correlation pada output SPSS Versi 22, sebagai berikut:

Tabel 1. Hasil Uji Validitas

Variabel Kepuasan Nasabah (X1)

\begin{tabular}{|c|c|c|c|}
\hline $\begin{array}{c}\text { No. Item } \\
\text { Pernyataan }\end{array}$ & $r_{\text {hitung }}$ & $r_{\text {tabel }}$ & Keterangan \\
\hline 1 & 0,283 & 0,181 & Valid \\
\hline 2 & 0,542 & 0,181 & Valid \\
\hline 3 & 0,581 & 0,181 & Valid \\
\hline 4 & 0,571 & 0,181 & Valid \\
\hline 5 & 0,500 & 0,181 & Valid \\
\hline 6 & 0,483 & 0,181 & Valid \\
\hline 7 & 0,443 & 0,181 & Valid \\
\hline 8 & 0,502 & 0,181 & Valid \\
\hline 9 & 0,400 & 0,181 & Valid \\
\hline 10 & 0,400 & 0,181 & Valid \\
\hline 11 & 0,196 & 0,181 & Valid \\
\hline 12 & 0,300 & 0,181 & Valid \\
\hline 13 & 0,454 & 0,181 & Valid \\
\hline 14 & 0,427 & 0,181 & Valid \\
\hline
\end{tabular}

Tabel 2. Hasil Uji Validitas Variabel Citra Bank (X2)

\begin{tabular}{|c|c|c|c|}
\hline $\begin{array}{c}\text { No. Item } \\
\text { Pernyataan }\end{array}$ & $r_{\text {hitung }}$ & $r_{\text {tabel }}$ & Keterangan \\
\hline 1 & 0,289 & 0,181 & Valid \\
\hline 2 & 0,391 & 0,181 & Valid \\
\hline 3 & 0,386 & 0,181 & Valid \\
\hline 4 & 0,484 & 0,181 & Valid \\
\hline 5 & 0,376 & 0,181 & Valid \\
\hline 6 & 0,299 & 0,181 & Valid \\
\hline 7 & 0,286 & 0,181 & Valid \\
\hline 8 & 0,491 & 0,181 & Valid \\
\hline 9 & 0,396 & 0,181 & Valid \\
\hline 10 & 0,457 & 0,181 & Valid \\
\hline
\end{tabular}

\begin{tabular}{|c|c|c|c|}
\hline 11 & 0,489 & 0,181 & Valid \\
\hline 12 & 0,461 & 0,181 & Valid \\
\hline 13 & 0,582 & 0,181 & Valid \\
\hline 14 & 0,519 & 0,181 & Valid \\
\hline
\end{tabular}

Tabel 3. Hasil Uji Validitas Variabel Loyalitas Nasabah (Y)

\begin{tabular}{|c|c|c|c|}
\hline $\begin{array}{c}\text { No. Item } \\
\text { Pernyataan }\end{array}$ & $r_{\text {hitung }}$ & $r_{\text {tabel }}$ & Keterangan \\
\hline 1 & 0,280 & 0,181 & Valid \\
\hline 2 & 0,409 & 0,181 & Valid \\
\hline 3 & 0,337 & 0,181 & Valid \\
\hline 4 & 0,492 & 0,181 & Valid \\
\hline 5 & 0,460 & 0,181 & Valid \\
\hline 6 & 0,306 & 0,181 & Valid \\
\hline 7 & 0,442 & 0,181 & Valid \\
\hline 8 & 0,584 & 0,181 & Valid \\
\hline 9 & 0,335 & 0,181 & Valid \\
\hline 10 & 0,498 & 0,181 & Valid \\
\hline 11 & 0,402 & 0,181 & Valid \\
\hline 12 & 0,492 & 0,181 & Valid \\
\hline 13 & 0,567 & 0,181 & Valid \\
\hline 14 & 0,404 & 0,181 & Valid \\
\hline
\end{tabular}

Sumber: Hasil Penelitian (data diolah, 2019)

Dari tabel di atas dapat disimpulkan bahwa masing-masing pernyataan untuk setiap variabel (X1, X1, dan Y) dinyatakan valid, karena memiliki $r_{\text {hitung }}>r_{\text {tabel }}$.

2. Uji Reliabilitas

Suatu instrumen dikatakan Reliabel apabila nilai Cronbach's Alpha> 0,600. Hasil uji realibilitas dapat dilihat pada tabel berikut:

Tabel 4. Hasil Uji Reliabilitas

\begin{tabular}{|c|c|c|}
\hline Variabel & Cronbach's Alpha & N of Item \\
\hline $\begin{array}{c}\text { Kepuasan } \\
\text { Nasabah }\end{array}$ & 0,663 & 14 \\
\hline Citra Bank & 0,651 & 14 \\
\hline $\begin{array}{c}\text { Loyalitas } \\
\text { Nasabah }\end{array}$ & 0,663 & 14 \\
\hline
\end{tabular}

Sumber: Hasil Penelitian (data diolah, 2019) 
Berdasarkan hasil tabel di atas dapat dilihat bahwa setiap variabel memiliki Cronbach's Alpha $>0,600$ sehingga dapat disimpulkan bahwa setiap variabel (X1, X1, dan Y) adalah reliabel.

3. Uji Asumsi Klasik

a) Uji Multikolinearitas

Suatu model regresi dinyatakan bebas dari multikolineriatas apabila nilai Tolerance lebih besar dari 0,1 (nilai Tolerance> 0,1) dan jika nilai VIF (Variance Inflaction Faktor) lebih kecil dari 10 (nilai $\mathrm{VIF}<10$ ). Hasil uji multikolineritas penelitian ini sebagai berikut:

Tabel 5. Hasil Uji Multikolineritas

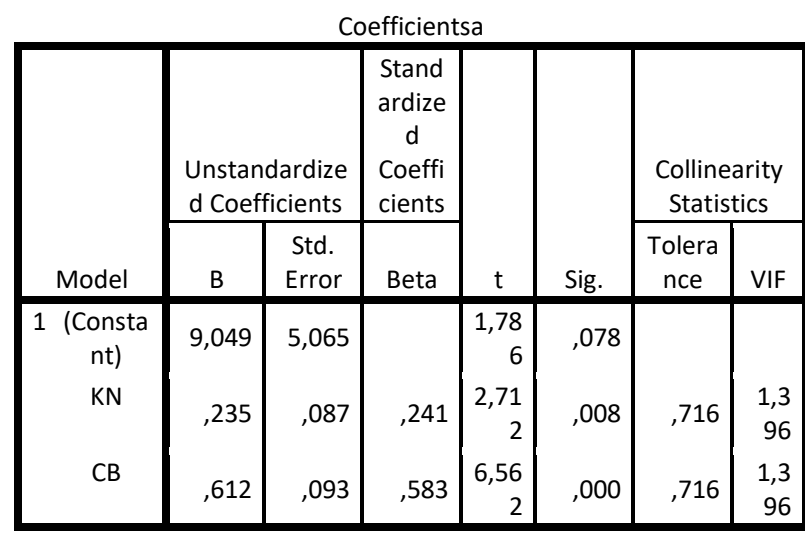

Sumber: Hasil Penelitian (data diolah, 2019)

Berdasarkan tabel di atas dapat diketahui nilai Tolerance dari variabel kepuasan nasabah adalah $0,716>0,1$, dan variabel citra bank adalah $0,716>0,1$ sehingga bebas dari multikolineritas. Selanjutnya berdasarkan nilai VIF dari variabel kepuasan nasabah adalah $1,396<10$, variabel citra bank adalah 1,396 < 10,sehingga bebas dari multikolineritas.

b) Uji Heterokedastisitas
POINT Vol. 2, No. 1, Jul 2021

Uji heteroskedastisitas merupakan uji yang dapat dilakukan untuk melihat penyimpangan terhadap faktor pengganggu. Artinya faktor pengganggu selalu sama pada data pengamatan yang satu ke data pengamatan yang lain tidak dipenuhi maka terjadi penyimpangan (heterokedastisitas). Model regresi yang baik adalah tidak terjadi heterokedastisitas yang dapat dilihat jika tidak terdapat pola tertentu pada grafik, seperti titittitik yang ada membentuk suatu pola tertentu yang teratur (bergelombang, melebar kemudian menyempit).

\section{Gambar 1. Uji Heterokedastisitas}

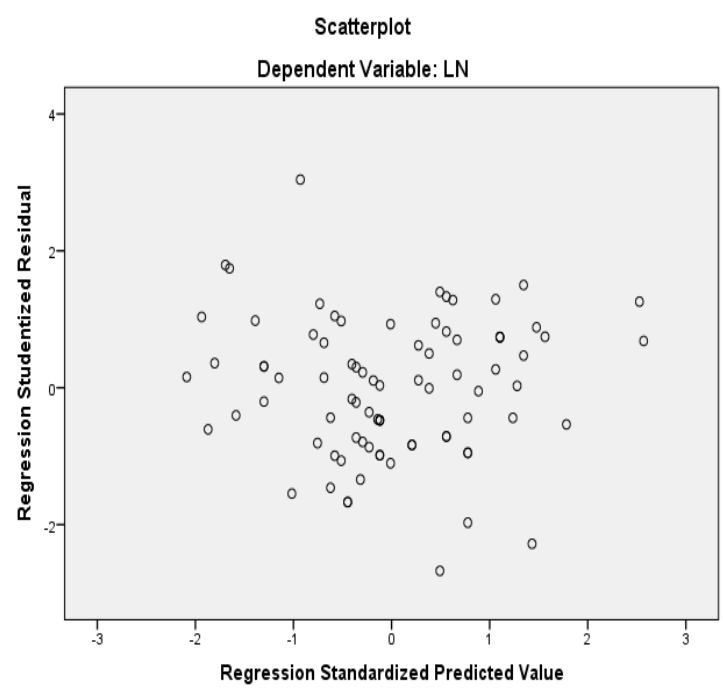

4. Analisisi Regresi Lenear Berganda

Analisis regresi linear berganda yang digunakan pada penelitian ini untuk mengetahui pengaruh variabel dependen $(X)$ terhadap variabel dependen $(\mathrm{Y})$ pada PT. Bank Muamalat Indonesia, Tbk. Kantor Cabang Pembantu Panyabungan. 
Tabel 6. Hasil Uji Analisis Regresi Linear Berganda

\begin{tabular}{|c|c|c|c|c|c|c|c|}
\hline \multirow[b]{2}{*}{ Model } & \multicolumn{2}{|c|}{$\begin{array}{l}\text { Unstandardize } \\
\text { d Coefficients }\end{array}$} & \multirow{2}{*}{$\begin{array}{l}\text { Stand } \\
\text { ardize } \\
d \\
\text { Coeffi } \\
\text { cients }\end{array}$} & \multirow[b]{2}{*}{$\mathrm{t}$} & \multirow[b]{2}{*}{ Sig. } & \multicolumn{2}{|c|}{$\begin{array}{l}\text { Collinearit } \\
\text { y Statistics }\end{array}$} \\
\hline & B & $\begin{array}{l}\text { Std. } \\
\text { Error }\end{array}$ & & & & $\begin{array}{c}\text { Tole } \\
\text { ranc } \\
\text { e }\end{array}$ & VIF \\
\hline $\begin{array}{c}1 \text { (Consta } \\
\text { nt) }\end{array}$ & 9,049 & 5,065 & & 1,786 & 078, & & \\
\hline $\mathrm{KN}$ & 235 & 087, & 241 & 2,712 & ,008 & 716 & $\begin{array}{r}1,3 \\
96\end{array}$ \\
\hline$C B$ & 612 & 093, & ,583 & 6,562 & ,000 & 716 & $\begin{array}{r}1,3 \\
96\end{array}$ \\
\hline
\end{tabular}

Sumber: Hasil Penelitian (data diolah, 2019)

Berdasarkan tabel di atas dapat dilihat pada kolom Unstandardized Coefficients pada bagian kolom B, dengan persamaan sebagai berikut:

$\mathrm{Y}=\mathrm{a}+\mathrm{b}_{1} \mathrm{X}_{1}+\mathrm{b}_{2} \mathrm{X}_{2}+\mathrm{e} \quad \mathrm{LN}=\mathrm{a}+\mathrm{b}_{1} \mathrm{KN}+\mathrm{b}_{2} \mathrm{CB}+$ e

$\mathrm{LN}=9,049+0,235 \mathrm{KN}+0,612 \mathrm{CB}+\mathrm{e}$

Persamaan regresi tersebut dapat dijelaskan sebagai berikut:

a. Nilai konstanta sebesar 9,049, artinya apabila variabel kepuasan nasabah dan citra bank bernilai 0 , maka loyalitas nasabah nilainya sebesar 9,049.

b. Nilai koefisien variabel kepuasan nasabah adalah 0,235, dapat diartikan bahwa setiap peningkatan kepuasan nasabah sebesar 1 satuan, maka loyalitas nasabah juga akan meningkat sebesar 0,235 satuan.

c. Nilai koefisien variabel citra bank adalah 0,612, dapat diartikan bahwa setiap peningkatan citra bank sebesar 1 satuan, maka loyalitas nasabah juga akan meningkat sebesar 0,612 satuan.

5. Uji Hipotesis

Uji Signifikansi Parsial (Uji t)

Uji t digunakan untuk mengetahui apakah kepuasan nasabah dan citra bank secara signifikan berpengaruh terhadap loyalitas nasabah. Ketentuan uji $\mathrm{t}$ dalam dua pihak adalah: jika $t_{\text {hitung }}<-t_{\text {tabel }}$ atau thitung $>$ ttabelmakaHoditolak dan Ha diterima dan jika $-t_{\text {tabel }} \leq t_{\text {hitung }} \leq t_{\text {tabel }}$ maka Ho diterima danHa ditolak.

Untuk $t_{\text {tabel }}$ dicari dengan menggunakan tingkat signifikansi $10 \%$ atau 0,1, maka diperoleh ttabel sebesar 1,663. Variabel kepuasan nasabah memiliki thitung sebesar 2,712 dan nilai Sig. Sebesar 0.008. Jadi dapat disimpulkan $t_{\text {hitung }}>t_{\text {tabel }}(2,712>1,663)$ dan nilai Sig. $<\alpha(0,008<0,1)$, maka kepuasan nasabah berpengaruh terhadap loyalitas nasabah PT. Bank Muamalat Indonesia, Tbk Kemudian variabel citra bank juga berpengaruh terhadap loyalitas nasabah PT. Bank Muamalat Indonesia, Tbk. Kantor Cabang Pembantu Panyabungan karena $t_{\text {hitung }}>t_{\text {tabel }}(6,562>$ $1,663)$ dan nilai Sig. $<\alpha(0,000<0,1)$. Kantor Cabang Pembantu Panyabungan. Karena semakin nasabah merasa puas dengan apa yang diberikan oleh bank maka loyalitas nasabah terhadap PT bank Muamalat Indonesia, Tbk. Kantor Cabang Pembantu Panyabungan akan semakin tinggi.

Uji Signifikansi Simultan (Uji F) 
Uji $\mathrm{F}$ digunakan untuk menunjukkan apakah semua variabel independen yang dimasukkan dalam model mempunyai pengaruh bersama-sama terhadap variabel dependen.

Tabel 7. Hasil Uji Signifikansi Simulltan (Uji F)

\begin{tabular}{|r|r|r|r|r|r|}
\hline Model & $\begin{array}{c}\text { Sum of } \\
\text { Squares }\end{array}$ & df & $\begin{array}{c}\text { Mean } \\
\text { Square }\end{array}$ & $\mathrm{F}$ & Sig. \\
\hline $\begin{array}{r}\text { Regres } \\
\text { sion }\end{array}$ & 379,446 & 2 & 189,723 & 48,419 & ,000b \\
Resid & 313,470 & 80 & 3,918 & & \\
ual & & & & & \\
Total & 692,916 & 82 & & & \\
\hline
\end{tabular}

Sumber: Hasil Penelitian (data diolah, 2019)

Hasil uji $F$ menunjukkan bahwa kepuasan nasabah dan citra bank mempunyai pengaruh secara simultan terhadap loyalitas nasabah, hal ini dapat dilihat dari uji F, dimana nilai $F_{\text {hitung }}>F_{\text {tabel }}(48,419>2,37)$.

6. Uji Koefisien Determinasi (R2)

Uji ini menunjukkan sumbangan pengaruh variabel independen terhadap variabel dependen. Koefisisen yang digunakan dalam penelitian ini yaitu nilai R Square.

\section{Tabel 8. Hasil Uji Koefisien Determinasi (R2)}

\begin{tabular}{|c|c|c|c|c|c|}
\hline \multicolumn{6}{|c|}{ Model Summaryb } \\
\hline Model & $\mathrm{R}$ & $\begin{array}{c}\mathrm{R} \\
\text { Square }\end{array}$ & $\begin{array}{l}\text { Adjusted } \\
\text { R Square }\end{array}$ & $\begin{array}{l}\text { Std. Error } \\
\text { of the } \\
\text { Estimate }\end{array}$ & $\begin{array}{l}\text { Durbin- } \\
\text { Watson }\end{array}$ \\
\hline 1 & ,740a & ,548 & ,536 & 1,979 & 2,044 \\
\hline
\end{tabular}

Sumber: Hasil Penelitian (data diolah, 2019)

Nilai R Square $\left(R^{2}\right)$ sebesar 0,548 , angka ini akan diubah ke bentuk persen yaitu $54,8 \%$, artinya loyalitas nasabah dipengaruhi oleh kepuasan nasabah dan citra bank dengan kontribusi sebesar 0,548 atau $54,8 \%$, sedangkan sisanya $45,2 \%$ yang dipengaruhi oleh variabel lain yang tidak diteliti dalam penelitian ini.

\section{PENUTUP}

\section{Kesimpulan}

Berdasarkan hasil penelitian secara parsial kepuasan nasabah dan citra bank berpengaruh terhadap loyalitas nasabah PT. Bank Muamalat Indonesia, Tbk., Kantor Cabang Pembantu Panyabungan. Kemuadian secara simultan kepuasan nasabah dan citra bank secara bersama-sama berpengaruh dan signifikan terhadap loyalitas nasabah.

\section{Saran}

Semoga adanya pengetahuan masyarakat terhadap minat produk perbankan syariah

\section{DAFTAR PUSTAKA}

Bank Muamalat Indonesia, Annual Report, Jakarta: Bank Muamalat Indonesia, 2018.

Evi Okatviani Satriyanti, " Pengaruh Kualitas Layanan, Kepuasan Nasabah Dan Citra Bank Terhadap Loyalitas Nasabah Bank Muamalat di Surabaya", dalam Jornal Of Business and Banking, Volume 2, No. 2, November 2012.

Firdaus Muhammad, Ekonometrika Suatu Pendekatan Aplikatif, Jakarta: PT Bumi Aksra, 2004.

Ekonometrika Suatu Pendekatan Aplikatif, Jakarta: PT Bumi Aksra, 2011.

Ismayanti Maulina, " Pengaruh Kualitas Layanan, Citra Bank dan Kepercayaan 
Terhadap Loyalitas Nasabah Bank BCA di Surabaya" (Artikel Ilmiah, Sekolah Tinggi Ilmu Ekonomi Perbanas, 2015).

Kasmir, Manajemen Perbankan, Jakarta: Rajawali Pers, 2014.

Mamang, Etta Sangadji \& Sopiah, Perilaku Konsumen, Yogyakarta: CV Andi Offset, 2013.

Noor Juliansyah, Metode Penelitian, Jakarta: Kencana, 2010.

Sugiyono, Metode Penelitian Bisnis, Bandung: Alfabeta, 2007.
Umar Husein, Metode Penelitian Untuk Skiripsi dan Tesis Bisnis, Jakarta: rajawali Pers, 2013.

Undang-undang Republik Indonesia Nomor 21 Tahun 2008 tentang Perbankan Syariah. 2008. Jakarta: Kementrian Hukum dan HAM Republik Indonesia.

Wiratna, V. Sujarweni, Metode Penelitian Bisnis Dan Ekonomi, Yogyakarta: Pustaka baru Press, 2015. 